\title{
Role of macroeconomic factors predicting financial performance of commercial banks in Nepal
}

\section{Prakash Kumar Gautam ${ }^{1}$ and Tenish Gautam ${ }^{2}$}

${ }^{1}$ Assitant Professor, Faculty of Management,Tribhuvan University, Nepal, Email: prakash.gautam@sdc.tu.edu.np, https://orcid.org/0000-0002-2197-3851

${ }^{2}$ Research Fellow, Nepal Mega College, Tribhuvan University, Nepal, Email: tgtggautam@gmail.com

Received date: October 20, 2021

Revised date: November 18, 2021

Accepted date: December 16, 2021

\section{Cite this paper}

Gautam, P. K. and Gautam, T. (2021).

Role of macroeconomic factors predicting financial performance of commercial banks in Nepal. International Research Journal of Management Science, vol.6(1), pp. 39-52

Copyright (C) Prakash Kumar Gautam and Tenish Gautam

https://doi.org/10.3126/irjms.v6i1.42337

\begin{abstract}
Purpose: This study analyzes the effect of macroeconomic indicators such as domestic products, interest rate, inflation rate, and unemployment rate on the financial performance of commercial banks in Nepal.

Design/Methodology: Five top commercial banks based on the financial performance were selected with stratified sampling, with secondary data of ten years. Hausman test was used to examine the endogeneity issue in the predictor variables and the effect of predicators on financial performance were estimated using OLS estimation (random effect model).
\end{abstract}

Findings: The study result revealed significant influence of macroeconomic factors except the unemployment rate for estimating ROE of commercial banks in Nepal while no significant impact was revealed for ROA. Among the significant variables, GDP contributes more in predicting the financial performance of commercial banks in Nepal.

Implication: As the study found significant role of macroeconomic variables to estimate ROE, bank administrators, government officials, and investors can focus in such variables, especially in GDP for competitive financial performance. They need to develop products based on macroeconomic variables. Besides, this study finds and tries to mitigate the gap in findings of previous empirical studies.

Originality/value: This study contributes to the literature on macroeconomic determinants predicting financial performance of banks, more specifically in finding the gap in determining ROA and ROE within the country specific issue.

Keywords: Financial performance, macroeconomic factors, ROE, ROA, interest rate, inflation rate, unemployment rate. 


\section{Introduction}

In context to Industrial Revolution 4.0 and the current Covid-19 pandemic, banking industry plays vital role in economic progress. Banks provide strong support for economic growth and development (Horobet, Radulescu, Belascu, \& Dita, 2021). In this context, the performance of banks becomes the central interest to bankers, government officers, investors and common people as it influences the entire economic development process. Thus, the banks' profitability analysis is becoming core attention of different scholars from the globe (Alarussi,\&Alhaderi, 2018; Nanda,\& Panda, 2018). Banks with good performance contribute to the employment generation, exchange rate stability, generating capital for manufacturing and trading industries for overall economic growth (Epstein, Shapiro, \& Gonzalez, 2017; Lazar, 2016; Ongore,\& Kusa, 2013), tend to engage in innovative activities (Odusanya, Yinusab,\&Ilo, 2018) and grow (Horobet, Radulescu, Belascu, \& Dita, 2021; Lee, 2014).

Bank performance can be measured in terms of profitability and is measured in terms of Return on Assets (ROA), Return on Equity (ROE), Net Interest Margin (NIM) and Liquidity. ROA determines how effectively the organization has transformed assets into profit (Osamwonyi,\& Michael, 2014); therefore, it is considered as one of the best measures of profitability to assess the efficiency and effectiveness of the bank's management in resource mobilization.

Bank specific factors like higher capital adequacy ratio, management efficiency, and liquidity management have shown direct relationship with ROA and ROE (Rai et al., 2018) and NIM (Gupta et al., 2018). Likewise, researches have established the direct relationship between GDP growth rate and the inflation rate with ROA, ROE and NIM. In this way, bank profitability is found to be affected by several factors i.e. bank specific (Asimakopoulos, Samitas, \& Papadogonas, 2009; Goddard, Tavakoli, \& Wilson, 2005;Samiloglu \& Demirgunes, 2008) and macroeconomic variables (Bolarinwa, Obembe,\& Clement, 2019; Nanda,\& Panda, 2018; Odusanya, Yinusab, \& Ilo, 2018; Pradhan,\& Shrestha, 2016; Khrawish, 2011, Kandir, 2008).

Macroeconomic factors are defined as the larger aspect of the economy such as inflation, gross domestic product, national income, per capita income, exchange rates, interest rates, unemployment level, financial crisis (Ozatac, Taspinar, El Rifai, \&Eren, 2018). The effects of macroeconomic factors cover a wider populace and indicate how the country's economy operates (Lynn, 2013). Macro economic factors reside in general environment because of which organizational control over the macroeconomic variables remain low (Dioha et al., 2018; Aguiar,\& Borner, 2006) which increases the need of managerial efficiency (Lawa, Zogli, and Dlamini, 2021; Ngweshemi,\& Isiksal, 2021) to overcome challenges and to grab opportunities induced by environmental factors.

There are mixed findings of effects of macroeconomic variables on the financial performance of banks. Sopan(2021), Bhattarai(2018), Pradhan et al.(2016) reported no significant role of macroeconomic variables like gross domestic products and inflation rate in predicting financial performance while significant positive influence of exchange rate. Alpera and Anbar (2011) reported positive significant 
impact of real interest rate in determining the performance of commercial banks. In contrary, Ngweshemi and Isiksal (2021) and Lawa, Zogli, and Dlamini (2021) reported non-significant influence of GDP and inflation rate on bank performance. This study aims to address the gap in the literature ofmacroeconomic (GDP, inflation rate, interest rate and unemployment rate) influence on the financial performance of commercial banks with empirical evidences.

\section{Review of literature}

Each business in the current situation need to operate in flexible and volatile business environment and the banks are no exception. Economic conditions i.e. macro economic factors influence to the financial performance of the banks (Kirimi, Kariuki, \&Ocharo, 2020; Brahmaiah, \&Ranajee, 2018,Petria, Capraru, \&Iulian, 2015). GDP, inflation rate, interest rate, and exchange rate have been established strong significant macroeconomic variables influencing the financial performance of banks (Neupane, 2020; Simiyu,\&Ngile, 2015; Bhattarai, 2015;Saeed, 2014).

Financial performance can be influenced by the crisis situation i.e. macroeconomic variables which are almost out of control of the organiztaion(Dewi et al., 2019). Saeed (2014) and Baba and Nasieku (2016) revealed negative impact of GDP and inflation rate on ROA and ROE in the study of financial institutions in UK during the crisis of 2008. Contrarary, Brahmaiah and Ranajee (2018) established significant positive effect on profitability and credit which was supported by the findings of Dewi et al. (2019) and Koe (2020). Similarly, Leon (2020) and suggested a negative influence of GDP on ROA and ROE which was supported by the study of Al-Jafari, Altaee,and Adam (2021) in Indian context.

Similarly, Bhattarai (2015) established negative relationship between exchange rate and non-performing loans indicating influence in profitability; a similar result revealed by Baba and Nasieku (2016), Koju et al. (2017) and Bhattarai (2018) while Dewi et al. (2019) found non-significant effect of exchange rate on ROA during the global economic crisis period.

Unemployment rate is becoming the attraction of researchers in estimating the financial performance of banking institutions. Studies have found negative influence of unemployment rate on financial performance (Baba, \&Nasieku, 2016). While Dewi et al. (2019) examined non-significant influence of unemployment rate on the performance.

Inflation rate, another important universal macroeconomic factor, has significant negative impact on ROA while positive effect on ROE (Koe, 2020; Brahmaiah, \&Ranajee, 2018; Homaidi et al., 2018). AlJafari, Altaee,and Adam (2021) revealed negative significant impact of inflation on bank profitability in Indian context. But, Dewi et al. (2019) revealed the non-significant influence of inflation rate on ROA. In contrary, Bhattarai (2019) and Leon (2020) revealed positive effect of inflation rate on ROA.

Interest rate has been taken as the predictor of bank profitability since long back. Usman (2020) revealed a significant positive impact on ROA supporting the findings of Kohlscheen, Pabón and Contreras (2018).

\section{Conceptual framework and hypothesis formulation}


Financial ratios like ROA and ROE are often used to measure financial performance of any organization (Issah, \&Antwi, 2017). These factors can be determined by macroeconomic factors such as GDP, interest rate, inflation rate, and unemployment rate. Availability of such measures can influence the financial performance though creative accounting, selection of accounting methods, and manipulations of figures that make the situation different (Chenhall, \&Langfield-Smith, 2007).

ROA and ROE were used as major tools for examining the performance of banks. ROA is widely used as a measure of firm performance (Benner,\& Veloso, 2008).Equity influences to the ROA while leverage influences to ROE (Hunjra, Chani, Javed, Naeem, \& Ijaz, 2014). In this study, GDP, Inflation rate, interest rate and unemployment rate were taken as the predicting variables to examine prediction of ROA and ROE in Nepalese commercial banks.

Return on assets (ROA). ROA is the return of the organization over an interval based on asset and costs of other factors of production. ROA measures the earnings before interest, tax, and extraordinary items, divided by net tangible assets (shareholder equity plusliabilities).ROA captures the fundamentals of business performance and operating capability in a holistic way (Issah, \&Antwi, 2017).

Return on equity (ROE). Return on equity is the ratio of net income and common equity. It measures the rate of common stockholder's investment. It sees over the utilization of funds that are supplied by shareholders. ROE is the rate of return to the shareholders (Hunjra, Chani, Javed, Naeem, \& Ijaz, 2014). GDP.GDP measures the total economic activities within a particular country and it is linked to increasing economic activities within the country. Commercial banks are intermediaries of money exchange in the economy which will lend to an improvement in the financial performance (Bikker, 2002). GDP is the most universally applied macroeconomic indicators to measure the total economic activities within an economy; a growth rate of the GDP reflects the state of an economic cycle (Podder, 2012).

H1a: Gross domestic product has a significant negative impact on ROA.

H1b: Gross domestic product has a significant negative impact on ROE.

Interest rate: Interest rate is the cost imposed as the proportion of the amount borrowed that is charged by the lender to the borrower for lending the money. The total interest rate on an amount lent or borrowed depends upon the principal, compounding frequency, and the time of borrowed and deposited. Interest rates affect both commercial banks and customers in two major ways: simple and compounded. They are forces to write off their debts into the profit of the company since it means the commercial bank is not able to recover both principal amount loan as well as expected interest from the customer (Makkar \& Singh, 2013).

H2a: Interest rate has a significant negative impact on ROA. $H 2 b$ : Interest rate has a significant negative impact on ROE. 
Inflation rate. The inflation rate is the percentage at which the currency is devalued during a period. It is also one of the factors that has been associated with the performance of commercial banks and some researchers have focused on establishing the relationship. Generally, high inflation rates lead to highinterest rates on loans and thus lead to higher income to commercial banks. Therefore, inflation is a continued increase in the price of services and goods in the long-term (Aquiar,\& Borner, 2006).

H3a: Inflation rate has a significant negative impact on ROA.

$H 3 b$ : Inflation rate has a significant negative impact on $R O E$.

Unemployment rate: The classical economists define unemployment rate as an excess supply of labor over the demand for labor which is caused by adjustment in real wages. Unemployment is the measure of the prevalence of unemployment, and it can be calculated by dividing the number of unemployed individuals by individuals currently in the labor force. Unemployment can be conceived as the number of people who are in an economy often given as a percentage of labor source (Jhingan, 2003) which will ultimately affect financial performance of the banks. Higher unemployment rate indicates the lower purchasing power of people that causes shrink in economic activities resulting in the lower financial performance (Horobet, Radulescu, Belascu, \& Dita; 2021).

H4a: Unemployment rate has insignificant positive impact on ROA. H4b: Unemployment rate has insignificant positive impact on ROE.

\section{Methodology, data and model}

The researcher used stratified sampling technique. Five commercial top five banks have been based on paid-up capital (about $20 \%$ of the population) from out of 27 commercial banks having at the top five highest paid-up capital (Global IME bank, Agriculture Development Bank, Nepal Investment Bank, Prime Commercial Bank, and NMB Bank). ROA and ROE were calculated by using the annual reports of sample commercial banks. Four macroeconomic factors (gross domestic product, interest rate, inflation rate and unemployment rate) were taken as the predicting variables. Secondary data of 10 years (2010/11 - 2019/20 i.e. 50 items) were collected from Nepal Rastra Bank economic bulletin and Central Bureau of Statistics, Nepal to include the fresh data in the analysis. The study has adopted analytical research design. Table 1 shows the number of commercial banks selected for the study along with study period and number of observations.

\section{The model estimation}

Performance of any organization is often examined with regression analysis Koe(2020), Tun (2019), Dewi et al.(2019) and Bagain (2018). Hausman test was used to test the endogeneity issue in the predictor variables. This study also used OLS estimation (Random effect model) to test the hypotheses. The function of a dependent variable, (i.e., financial performance) takes the following forms: 
Financial performance $=\mathrm{f}(\mathrm{GDP}, \mathrm{IR}, \mathrm{INF}$, and UM $)$

Model 1

Model 1aims to analyze the effect of macroeconomic variablespredicting the ROE. The model will be;

$\mathrm{ROE}_{\mathrm{it}}=\beta_{0}+\beta_{1} \operatorname{Real} G D P+\beta_{2} I R+\beta_{3} I N F+\beta_{4} U M+\epsilon_{i t}$

Model 2

Model 2aims to analyze the effect of macroeconomic variables predicting ROA. The model will be:

$\mathrm{ROA}_{\text {it }}=\boldsymbol{\beta}_{0}+\beta_{1}$ Real GDP $+\beta_{2} I R+\beta_{3} I N F+\beta_{4} U M+\epsilon_{i t}$

Where,

$\beta \_0=$ Constant term

GDP $=$ Real Gross Domestic Product

$\mathrm{IR}=$ Interest rate

$\mathrm{INF}=$ Inflation

$\mathrm{UM}=$ Unemployment

$\mathrm{ROE}=$ Return on equity as define by a percentage of net income on shareholders' equity

$\mathrm{ROA}=$ Return on asset as defined by a percentage of net income on total asset

$\beta \_1, \beta \_2, \beta \_3, \beta \_4=$ regression coefficient

$\epsilon=$ error items

$\mathrm{i}=$ commercial bank

$\mathrm{t}=$ index of a time

Result and Discussion

Descriptive statistics. This section summarizes the characteristics of the test variables. Their respective mean, range, standard deviation, and kurtosis values were considered along with graphs, key categorizations, and percentages.

Table 1: Descriptive statistics of the variables

\begin{tabular}{llllllllll}
\hline & Minimum & Maximum & Mean & Std. Deviation & Variance & \multicolumn{2}{c}{ Skewness } & \multicolumn{2}{c}{ Kurtosis } \\
\hline & Statistic & Statistic & Statistic & Statistic & Statistic & Statistic & Std. Error & Statistic & Std. Error \\
\hline ROE & 0.03 & 1.49 & 0.450 & 0.406 & 0.165 & 1.026 & 0.337 & -0.156 & 0.662 \\
ROA & 0.058 & 3.99 & 1.876 & 0.749 & 0.561 & -0.54 & 0.337 & -0.721 & 0.662 \\
log GDP & 14.18 & 15.06 & 14.64 & 0.292 & 0.085 & -0.071 & 0.337 & -1.27 & 0.662 \\
Interest rate & 6.54 & 10.47 & 8.935 & 1.09 & 1.187 & -0.836 & 0.337 & 0.158 & 0.662 \\
Inflation rate & 3.63 & 9.46 & 7.239 & 2.091 & 4.373 & -0.632 & 0.337 & -1.153 & 0.662 \\
Unemployment rate & 1.35 & 1.53 & 1.464 & 0.059 & 0.003 & -0.583 & 0.337 & -0.807 & 0.662 \\
\hline
\end{tabular}

Sources: Calculation using SPSS version 26

Research data of each variable was analysed against the ROA and ROE of the commercial banks over the period of 10 years. The result indicates the overall average return on equity and average return on assets for the commercial banks in the period was 0.450 and 1.876 respectively, indicating the low performance 
of the selected commercial banks. Over the study period, the average real GDP was 14.65 , the average change in interest rate was 8.94 , the average annual inflation rate was 7.24 and the average of the change in the unemployment rate was 1.46. All the series have a coefficient of Kurtosis of either less than or greater than 3 against the standard value of 3 for a normal distribution.

However, the minimum and maximum value of each variable over the period was also under consideration. The standard deviations from means of return on equity, real GDP, interest rate, inflation rate, and the unemployment rate were $0.41,0.29,1.09,2.09$ and 0.59 respectively. The finding indicates that the macro-economic variables are differently dispersed from the mean which is in agreement with a coefficient of kurtosis. The features of non-normality in the data exist.

Association between ROE with macro-economic variables. Correlation analysis was conducted to examine the relationship between $\mathrm{ROE}$ and the predictor variables.

Table 2:Test of association of ROE and ROA with macroeconomic variables

\begin{tabular}{lllllll}
\hline Variables & 1 & 2 & 3 & 4 & 5 & 6 \\
\hline ROE & 1 & & & & & \\
ROA & 0.423 & 1 & & & & \\
log GDP & $-.474^{* *}$ & 0.059 & 1 & & & \\
Interest rate (IR) & $-0.246^{* *}$ & 0.130 & 0.077 & 1 & & \\
Inflation rate (INF) & $.390^{* *}$ & -0.535 & $-.796^{* *}$ & $-.509^{* *}$ & 1 & \\
Unemployment rate & $.356^{*}$ & $-.641^{*}$ & $-.784^{* *}$ & $-.309^{*}$ & $.903^{* *}$ & 1 \\
\hline
\end{tabular}

${ }^{* *}$ Correlation is significant at the 0.01 level $\left(2\right.$-tailed), ${ }^{*}$ Correlation is significant at the 0.05 level (2-tailed).

The table 2 provides evidence that there was a significant negative correlation between return on equity and real gross domestic product $(\mathrm{r}=-0.474, \mathrm{sig}<0.01)$. There is a negative significant correlation between $\mathrm{ROE}$ and interest rate $(\mathrm{r}=-2.46 \mathrm{sig}=0.045<0.05)$. Likewise, there is also a weak positive significant association of ROE with inflation rate $\left(0.390^{* *}\right)$ and unemployment rate $\left(0.356^{*}\right)$.

Similarly, ROA has positive insignificant relationship with ROE, GDP and interest rate while negative insignificant correlation with inflation rate. ROA has significant negative relation with unemployment rate $(\mathrm{r}=-0.641, \mathrm{p}<0.1)$.

Analysis of the effect of macro-economic variables in predicting ROE and ROA.The effect of a macroeconomic variable on the return on equity of commercial banks in Nepal was investigated using multiple linear regression. The result is presented in table 3.

Table 3: Analysis of the effect of macro-economic variables in predicting ROE and ROA

\begin{tabular}{llllllll}
\hline & LNRGDP & Interest rate (IR) & Inflation rate (INF) & UM & Constant & R-Squared & Observations \\
\hline ROE (beta) & $-1.161^{* * *}$ & $-0.169^{* * *}$ & $-0.114^{*}$ & 0.635 & $18.86^{* * *}$ & 0.503 & 50 \\
t-statistics & 2.256 & 2.0511 & 2.0599 & -1.524 & -4.641 & & \\
\hline ROA (beta) & 0.025 & 0.109 & 0.144 & 0.144 & 7.767 & 0.04 & 50 \\
t-statistics & 0.412 & 0.85 & 0.981 & 1.191 & 1.321 & & \\
\hline
\end{tabular}

Standard errors in parentheses ${ }^{\star *} \mathrm{p}<0.01,{ }^{\star *} \mathrm{p}<0.05,{ }^{\star} \mathrm{p}<0.1$ 
The result (table 3) shows that higher real gross domestic product, interest rate, inflation rate and unemployment rate predict ROE significantly but has no significant influence in predicting ROA. The model predicting ROA has been found insignificant, therefore, the discussion on influence of each variable under study to ROA has been discarded. This implies that ROA could not be estimated by gross domestic product, interest rate, inflation rate and unemployment rate; further, provides evidence to reject $\mathrm{H} 1 \mathrm{a}, \mathrm{H} 2 \mathrm{a}, \mathrm{H} 3 \mathrm{a}$ and $\mathrm{H} 4 \mathrm{~b}$.

Result revealed (table 3 ) significant negative role in predicting ROE by real gross domestic product $(b=-$ $1.161, \mathrm{p}<0.001$ ), providing the evidence to accept H1b. This finding implies that an increase in RGDP leads to decrease in return in shareholders' equity. This finding is consistent with the findings of Koroleva, Shawuya, Anqi, and Angi (2021), Koe (2020), Leon (2020), Homaidi et al. (2018), Rashid and Jabeen (2016), Petria et al. (2015), Saeed (2014), Francis (2013), and Naceure(2003).

Further, the result revealed (table 3 ) significant negative effect of interest rate in $\operatorname{ROE}(b=-0.169, p<0.01)$, supporting evidence to accept $\mathrm{H} 2 \mathrm{~b}$. The finding implies that an increase in interest rate leads to decrease in financial performance of the commercial bank. The finding agreed with the study by Homaidi et al.(2018), Rashid and Jabeen (2016), Tiberiu (2015), and Saeed (2014) while challenged the conclusion of Baba and Nasiek (2016).

Similarly, the relationship between the inflation rate and ROE of the commercial banks is found to be negative and significant $(b=-0.114, p<0.1)$; providing the evidence to accept $\mathrm{H} 3 \mathrm{~b}$. This implies that an increase in inflation rate causes for poor financial performance of commercial banks. This finding supports the findings of Sufian and Habibullah (2009), Sufian and Chang (2008), Sufian (2009) and Perry (1992). Increase in inflation rate results in decreasing purchasing power of customers which shrinks the financial activities resulting negative effects in profitability of banks. Further, during the inflation period, business organizations hesitate to expand the business activities that result in decreasing loan disbursement and may be collection. This also results in poor profitability.

The relationship between the unemployment rate and ROE of a commercial bank is positive but insignificant $(b=0.635, p>0.1)$. This indicates that the unemployment problem has no significant effect on profitability of the bank providing evidence to reject the H4b. Unemployment rate is the number of unemployed workable people out of total population within specific time and location. It is known that the remittance contributes majority in GDP of Nepal which protected from low economic activities of people resulting low bank profitability. This result do not ignore the effect of unemployment rate on profitability as there is strong association as the result revealed by Horobet, Radulescu, Belascu, and Dita (2021).

\section{Conclusions and policy recommendation}

The main objective of the study was to capture the major effect of macroeconomic factors on financial performance of commercial banks in Nepal. Random effect models (ordinary least square multiple regression model) were employed by using annual data over the period 2010/11 to 2019/20. Financial performance (ROA and ROE) were estimated with the predicators: GDP, inflation rate, interest rate, and unemployment rate. Result revealed the evidence to refuse predicting ROA by macroeconomic variables while three macroeconomic variables (GDP, interest rate and inflation rate) were found to have predicting ability to ROE. Unemployment rate, in Nepalese context is found to be insignificant for predicting banks' financial performance. In a nutshell, this study concludes significant influence of major macroeconomic 
variables in profitability of the commercial banks. So, the bank administration is recommended to take care of the GDP, inflation rate and interest rate while making short-term and long-term strategies to excel the bank profitability.

Acknowledgement: Authors acknowledge finance managers and the friends for assistance in data collection and analysis process.

Funding: Authors have received no direct funding for conducting and publishing this research.

Conflict of interest: Authors declare the absence of any conflict of interest in this research paper.

\section{References}

Al-Homaidi, E. A., Tabash, M. I., Farhan, N. H., \&Almaqtari, F. A. (2018). Bank-specific and macro-economic determinants of profitability of Indian commercial banks: A panel data approach. Cogent Economics \& Finance, 6(1), 1-26.

Ademola, A., \&Badiru, A. (2017). The impact of unemployment and inflation on economic growth in Nigeria. International Journal of Business and Economic Sciences Applied Research, 9(1), 47-55.

Aguiar, M., \& Broner, F. A. (2006). Determining underlying macroeconomic fundamental during emerging market crises: Are conditations as bad Anstey seemed? Journal of Monetary Economic, 53(1), 699-724.

Alarussi, A. S., \&Alhaderi, S. M. (2018). Factors affecting profitability in Malaysia. Journal of Economic Studies,45(3), 442-458. doi:10.1108/JES-05-2017-0124

Al-Jafari, M. K., Altaee, H. H. A., \&Adam, M. H. M. (2021). Bank-Specific, Government-Specific and Macroeconomic Determinants of Profitability: Evidence from the Banking Sector of Saudi Arabia. Indian Journal of Economics and Business, 20(2), 315-328.

Alpera, D., \& Anbar, A. (2011). Bank Specific and Macroeconomic Determinants of Commercial Bank Profitability: Empirical Evidence from Turkey. Business and Economics Research Journal, 2(2), 139152.

Asimakopoulos, I., Samitas, A., \&Papadogonas, T. (2009). Firm-specific and economy wide determinants of firmprofitability: Greek evidence using panel data. Managerial Finance, 35(11), 930-939.

Assfaw, A. M. (2019). Firm specific and macroeconomic determinants of bank liquidity: emperical investigation from Ethiopian private commercial bank. Accounting Finance and Auditing Studies, 5(2), 123-145.

Athanasoglou, P. P., Brissimis, S. N., \& Delis, M. D. (2008). Bank Specific industry specific and macroeconomic determinants of bank profitability. Journal of International, Financial Markets, Institution and Money, 15(1), 121-136.

Baba, S., \&Nasieku, T. (2016). Effect of macroeconomic factors on financial performance of commercial banks in Nigeria. International Journal of Social Science and Information Technology, 2(1), 12781299. 
Benner, M., \& Veloso, F. M. (2008). ISO 9000 practices andfinancial performance: A technology coherenceperspective. Journal of Operations Management, 26,611-629.

Bhattarai, B. P. (2019) The determiants of profitability of commercial banks in Nepal. Accounting and Financial Manahement Research, 9(2), 5-20.

Bhattrai, B. P. (2018). Firm specific and macroeconoic variable effect of share price of Nepalese commercial bank and insurance companies. Global Review of Accounting and Financing, 9(1), 35-53.

Bhattarai, S. (2015). Determinants of Non- performing loan in Nepalese commercial banks. Economic Journal of Development, 19(1), 1-2.

Bikker, J. A., \& Hu, H. (2002). Cyclical patterns in profits, provisioning and lending of banks and procyclicality of the new basel capital requirements. BNC quartely Review, 221(2), 143-175.

Bolarinwa, S. Obembe, O. B., \& Clement, O. (2019). Re-examaning the determinants of bank profitability in Nigeria.Journal of Economic Studies, 46(3), 633-651. doi: 10.1108/JES-09-2017-0246

Brahmaiah, B. (2018). Factors influencing profitability of banking indian. Theoretical Economic Letters, 8(14), 3046-3061.

Chenhall, R. H., \&Langfield-Smith, K. (2007). Multipleperspectives of performance measures. European Management Journal,25(4), 266-282.

De Leon, M. (2020). The impact of credit risk and macroeconomic factors on profitability: the case of the ASEAN banks. Banks and Banks Systems, 15(1), 21-29.

Dewi, V. I., Tan Lian Soei, C., \&Surjoko, F. O. (2019). The impact of macroeconomic factors on firm's profitability. Evedence from the last moving consumer goods firms on lisred on indonesia stock exchange. Academy of Accounting and Financial Studies,23(1), 1-6.

Dietrich, A., \&Wanzenried, G. (2011). Determinants of bank profitability before and during the crisis: Evidence from Switzerland. International Financial Markets, Institution \& Money, 21(3), 307-327.

Dioha, C., Mohammed, N. A., \&Okpanachi, J. (2018). Effect of firm characteristics on profitability of listed consumer goods companies in Nigeria's. Journal of Accounting, Finance and Auditing Studies, $4(2), 14-13$.

Ekanayake, N. (2018). The impact of bank-specific and macro e conomic factors on non performing loan srilankan commercial bank. Modern Accounting and Auditing, 11, 611-627.

Epstein, B., Shapiro, F. A., \& Gonzalez, A. (2017). Financial disruptions and the cyclical upgrading of labor. Reviewof Economic Dynamics, 26, 204-224.

Fisher, S. (1993). The role of macroeconmic factors in growth. Monetary Economic, 32(2), 485-512. doi: 10.1016/0304-3932(93)90027-D.

Francis, M. E. (2013). Determinants of commercial bank Profitability in sub-saharan Africa. International Journal of Economics and Finances, 5(9), 134-147.

Goddard, J., Tavakoli, M., \& Wilson, J. (2005). Determinants of profitability in European manufacturing and services:Evidence from a dynamic panel model. Applied Financial Economics, 15(18), 12691282. 
Hasan, M. S. A., Manurung, A. H., \& Usman, B. (2020). Determinats of Bank profitability with size as moderating variable. Journal of Applied Finance and Banking,10(1), 153-166.

Horobet, A., Radulescu, M., Belascu, L., \& Dita, S. M. (2021). Determinants of Bank Profitability in CEE Countries: Evidence from GMM Panel Data Estimates. Journal of Risk and Financial Management, 14(7):307. doi: 10.3390/jrfm14070307

Hunjra, A. I, Chani, M. I., Javed, S., Naeem, S.,\& Ijaz, M.S. (2014). Impact of Micro EconomicVariables on Firms Performance. International Journal of Economics and Empirical Research. 2(2), 65-73.

Issah, M.,\&Antwi, S. (2017). Role of macroeconomic variableson firms' performance: Evidence from the UK.Cogent Economics \& Finance, 5(1), 1-18. doi:10.1080/23322039.2017.1405581

Jhingan, M. (2003).Advance Macroeconomic. Theory 11th Edition. Delhi: Vrinda Publications (P) LTD.

Kandir, S. Y. (2008). Macroeconomic variables, firmcharacteristics and stock returns: Evidence from Turkey.International Research Journal of Finance and Economics, 16, 35-45.

Khrawish, H. A.(2011). Determinants of commercial banks performance: evidence from Jordan.International Research journal of Finance and Economics, 8(1), 148-163.

Kirimi, P. N., Kariuki, S. N., \&Ocharo, K. N. (2020). Mediation effect of macro-economic factors on the relationship between banks' financial soundness and financial performance. International Journal of Finance and Accounting, 9(5), 99-109. doi: 10.5923/j.ijfa.20200905.01

Koe, V. (2020). Impact of bank specific and macroeconomic determinants on financial performance in commercial banks case study in Thailand and Vietan. International Journal of Social Science, 6(2), 514-534.

Koju, L., Koju, R., \& Wang, S. (2018). Macroeconomic and bank specific determinants of non-performing loans; evidence from Nepalese banking system. Center Banking and Practice, 7(3), 111-138.

Kohlscheen, E., Pabón, A. M., \& Contreras, J. (2018). Determinants of bank profitability in emerging markets. Monetary and Economic Department. Bank for International Settlements. BIS Working Papers No. 686.

Koroleva, E.,Shawuya,J., Anqi, M., \& Angi, S. (2021). DeterminantsAffecting Profitability of State-OwnedCommercial Banks: Case Study ofChina. Risks, 9(8): 150. doi:10.3390/risks9080150.

Lawa, E.,Zogli, L.-K. J., \& Dlamini, B. I. (2021).Investigating the determinants of bank performance in South Africa: A panel data analysis. Modern Perspectives in Economics, Business and Management, 8(27), 12-29. doi:10.9734/bpi/mpebm/v8/3961F.

Lazar, S. (2016). Determinants of firm performance: Evidence from Romanian listed companies. Review ofEconomics and Business Studies, 9(1), 53-69.

Lee, Y. (2014). The effects of firm specific factors and macroeconomics on profitability of property-liability insuranceindustry in Taiwan. Asian Economic and Financial Review, 4(5), 681-691.

Lynn, D. J. (2007). The rectonic force of global real estate; Implication for global investment and portfolio management. The Journal of Real Estate Portfolio, 13(1), 87-92. 
Maghyereh, A. I. (2012). Casual relations among stock price and macroeconomic variables in the small open economy in jorden.Open SSRN, Retrieved from:http://dx.doi.org/10.2139/ssrn.317539

Makkar, A., \& Singh, S. (2013). Analysis of the financial performance of indian commercial banks, A comperative study. Indian Journal of Finance, 7(1), 41-49.

Monilka, A., Azem, A. N., \& Teguh, S. I. (2021). The impact of Fintech development to profitabilit of Islamic Bank. International Journal of Research and Review, 8(1), 250-258.

Naceure, S. B. (2003). Determinants of the Tunisian banking industry profitability; pannel evidance. Universite Libre de Tuins Working Paper, 11(3), 317-319.

Nanda, S., \& Panda, K. A. (2018). The determinants of corporate profitability: An investigation of Indian manufacturingfirms. International Journal of Emerging Markets, 13(1), 66-86. doi: 10.1108/ IJoEM-01-2017-0013

Neupane, B. P. (2020). Profitability determinants of Nepalese commercial banks. PressAcademia procedia, 12(1), 40-50.

Ngweshemi, L. E., \&Isiksal, A. Z. (2021). Analysis of the factors affecting bank profitability: Evidence of Tanzania commercial banks. Sustainable Economic Development: Pattern and Perspective, 39(8). doi: $10.25115 /$ eea.v39i8.4768

Odusanya, I. A., Yinusab, O. G., \&Ilo, B. M. (2018). Determinants of firm profitability in Nigeria: Evidence fromdynamic panel models. SPOUDAI Journal of Economics and Business, 68(1), 43-58.

Ojha, P. R. (2018). Macro economic and bank specific factor affecting liquidity. A study Nepalese commercial bank. Business and Social Science, 2(1), 79-87.

Ongore, V. O., \& Kusa, G. B. (2013). Determinants of financial performance of commercial Banks in Kenya. International Journal of Economic and Finacial issue, 3(1), 237-252.

Osamwonyi, I. O., \& Michael, C. I. (2014). The impact of macroeconomic variables on the profitability of listed commercial banks in Nigeria. European Journal of Accounting Auditing and Finance Research, 2(10), 85-95.

Otieno, M. O. (2013). The determinants of commercial banks profitability in Kenya (1983-2012). University of Nairobi E-Respository. Retrieved from: http://erepository.uonbi.ac.ke:8080/xmlui/handle/123456789/60496

Ozatac, N., Taspinar, N., El Rifai, O., \&Eren, B. (2018). The relationship between government expenditure on education and economic growth: The case of France. In: Procházka, D. (eds). The impact of globalization on international finance and accounting. Springer Proceedings in Business and Economics.doi:10.1007/978-3-319-68762-9_7

Ozili, P. K. (2021). Bank profitability determinants: comparing the united states, Nigeria and South Africa. International Journal of Banking and Finance 16(1), 55-78.

Padachi, K. (2006). Trend in working capital management and its impact on firms perfromacne: An analysis of maufacturing firms. International Review of Business Research Paper, 2(2), 45-58. 
Petria, N., Capraru, B., \&Ihnatov, I. (2015). Determinants of banks' profitability: Evidence from EU 27 banking systems. Procedia Economics and Finance, 20(15), 518-524.

Perry, P. (1992). Do banks gain or lose from inflation?Journal of Retail Banking, 14(2), 25-40.

Podder, B. (2012). Determinants of profitability of private commercial banks in Bangladesh; An emperical study A thesis for a professsion master in Banking and Finance. Asian Institution of Technology, Thailand. Retrieved from: http://www.bankingandfinance.ait.asia

Pradhan, R. S. (1896). Public Corporation of Nepal: A Case Study of Financial Ratios. New Delhi: National Book organization.

Pradhan, R. S., \&Shrestha, R. (2016). Impact of Bank Specific and Macroeconomic Variables on the Performance of Commercial Banks of Nepal. doi:10.2139/ssrn.2793530

Rai, P., Ojha, P., Singh, P., Gyawali, R., \& Gupta, R. (2018). Determinants of Financial Performance in Nepalese Financial Performance. Retrieved from: https://dx.doi.org/10.2139/ssrn.3101740.

Rashid, A., \&Jabeen, S. (2016). Analyzing performance determinants: Conventional versus Islamic banks in Pakistan. Borsa Istanbul Review, 16(2), 92-107.

Saeed, M. S. (2014). Bank related, industry- related and macro-economic factors affecting Bank profitability; A case of the united kingdom. Finance and Accounting, 5(2), 42-50.

Samiloglu, F., \&Demirgunes, K. (2008). The effect of working capital management on firm profitability: Evidencefrom Turkey. The International Journal of Applied Economics and Finance, 2(1), 44-50.

Sayedi, S. (2013). Bank specific Industrial specific and macroeconomic determinants of bank profitability in Nigeria. Journal of Finance,6(7). 125-134.

Shahid, M. (2014). Effect of inflation and unemployment on economic growth in Pakistan. Journal of Economics and Sustainable Development,5(15), 103-106.

Simiyu, C. N., \&Ngile, L. (2015). Effect of macroeconomic variables on profitability of commercial banks listed in the Nairobi securities exchange. International Journal of Economics, Commerce and Management, 3(4).

Sopan, J. (2021). Credit growth and asset delinquency in Indian banks. Asian Journal of Research in Banking and Finance, 11(6-7), 8-16.

Sufian, F., \& Habibullah, M. S. (2009). The impact of Asian financial crisis on bank perfrormance: Emperical form Thailand and Malaysia. Savings and Development, 33(2), 153-181.

Sufian, F. (2009). Assessing the impact of mergers and acquisitions on bank profit efficiency: Empirical evidence from Malaysia. International Journal Decision Sciences, Risk and Management, 1(3-4), 258-285. 
Sufian, F.,\&Chong, R. R. (2008). Determinants of bank profitability in a developing economy: Empirical evidence from the Philippines.Asian Academy of Management Journal of Accounting and Finance, 4(2), 91-112.

Tiberiu, C. (2015). Banks' profitability and financial soundness indicators: A macro level investigation in emerging countries. Procedia economics and finance, 23(1), 203-209.

Tun, N. N. (2019). An emperical analysis of macro economic factor affecting on deposit mobilization of private commercial banks in Myanmar. Journal of Recent Trend in Business and Tourism, 3(2), 38-47.

Yesmine, S., \& Uddin, M. S. (2015). Determinants of banks financial performance: A comparative study between nationalized and local private commercial banks of Bangladesh. International Journal of Business and Management Invention, 4(9), 33-39. 